\title{
Race and religion: the Hindu perspectives
}

\author{
Arjun Dubey \\ Applied Sciences \&Humanities, Madan Mohan Malaviya Engineering College, Gorakhpur, Uttar Pradesh, India
}

Email addresses:

arjun.dubey@rediffmail.com

\section{To cite this article:}

Arjun Dubey. Race and Religion: The Hindu Perspectives. Humanities and Social Sciences. Vol. 1, No. 1, 2013, pp. 7-10. doi: 10.11648/j.hss.20130101.12

\begin{abstract}
The author's attempt in the paper is to present race and religion in global context on the one hand and to analyse the same in Indian perspectives in general and the Hindu outlook in particular on theother hand. The quotes and references from Hindu Scriptures are given in the paper to clearly illustrate the values and ethics in Sanatana Dharma, a synonym used for Hinduism. The meaning and concept of Hinduism can best be known by understanding the types of lives the Hindus live on Indian soil. Also, the significance of this timeless religion can be known when one comes across how Hindus treat the people in humanistic manner. In this context, it is a subject of knowing this truth that the Hinduism has ever been welcoming the arrival of different races and religions and has been adapting and assimilating their good aspects and the eternal values, thus giving another broader outlook and liberal nature of Hindus that make them Indian with pride and dignity.
\end{abstract}

Keywords: Hindu, Race, Religion, Sanatana, Scriptures, Upanishad

\section{Introduction}

Ever since man, as a race, came upon this earth, he has been making substantial development in all the walks of his life. Living life in any manner though infatuates many people and they, therefore, advocate for total emancipation, without restrictions, yet, the majority of people prefer to live life fearlessly, with security and safety. They wish to establish such value system that must survive for a long time, and that should also be acceptable to all. They believe they must have freedom in their personal affairs which do not harm anyone including their kith and kin. They also see that their acts do not give any negative message even to their family members. They remain particular in attaining and sustaining the values in families and always strive to create harmony in their families through love, care and sacrifice.

Man is one of the races that nature has gifted this earth along with animals, plants and many other things that are both similar and dissimilar to each other. Often man is either compared or contrasted with animals in manifold manners. The animals' life, it is observed, is without creativity with change. There is a little amount of creativity in birds' activities, but there is hardly any difference in the shape and make of their designs. They have been making their houses to live in without making any changes, using the same age-old conventional materials .But, with the human beings the picture is different. They have been using different materials for different purposes with different designs. Also, it is interesting to observe that their creativity has sprung from the ideas and thoughts brought out by them from time to time. It is sheer due to creativity with change that man has made development in all the domains--from matter to mind.

\section{Article}

If one looks at human history in religious and cultural context, one will find that it has never remained uniform and constant the world over. Religion is a subject that has widely been discussed by all the human societies. The practices with respect to adapting and performing rituals, accepting and propagating myths and beliefs and offering prayers for miraculous and unseen agents etc. gradually formed the shape of religion in one way or the other by human groups and societies. India is a typical land where one observes all types of religious practices by various human races living here in various manners. We can see the Hindus having deep belief in and faith for Sanatana religion that emerged even before the birth of civilization; Buddhism which came out of Hinduism has its strong roots in India and many Asian countries; Christianity that was born in Jerusalem with Jesus 's miraculous arrival on this earth through the sacred womb of Maryam and that widely 
flourished in Europe too started finding its religious roots in the beginning of the first century in Kerala, which is today the most educationally developed state of India, and this religion is adopted and practised by a large number of people of North East region and other states of India ; Islam ,that originated in Arab by $5^{\text {th }}$ century A.D.,and that believes in union of humans through its religious practices, got its touch in India by the invaders due to geographical proximity, but at the same time, this religion also attracted the people for its Sufis' practices and their metaphysical beliefs. A large number of people from all the religious sections of society visit the shrines of these Sufis at Ajmer in Rajasthan, Deva Sarif near Lucknow, in U.P.,Nizamuddin Auliah in Delhi and several other places. There are many other religions that are widely practiced on Indian soil in different ways. In fact, India is the confluence of religious heterogeneity, harmonised with national homogeneity.

The Hindus practice the Sanatana Dharma that is the oldest religion. Other religions, such as,Jainism,Buddhism,Sikkh etc were born as a result of protest against and reformation in the then Hindu religious practices. But, again during early $9^{\text {th }}$ century, it got its revival with the efforts of Shri Adi Shankaracharya.The protests against or the acceptance for Sanatana Dharma has been based more on ideological beliefs than on sheer personal observations. Of course, personal faith and belief have also amounted to religious protest or acceptance. In India, Buddhism was born as result of teaching of and personal experiences of Kumar Siddhartha, who was acknowledged as Buddh, for he attained knowledge, the truth, the wisdom and realization under the shade of , known as, Buddha Vriksh, a sacred tree at Gaya in Bihar. But, what Lord Buddha spoke about his realizations are not radically contrary to Hinduism. His beliefs of and advocacy for love, compassion and non-violence are in line with Sanatana Dharma. The difference lies with the philosophies of Brahmanism that does not either compromise with the practices of other religions or absorb them with it. It is worth noting to remember that Brahmanism acknowledges the power of Brahm i.e. the truth and the ultimate reality, and, no doubt, it is very difficult to reach to this stage, and about which a very few sages and saints have known a little till date. However, Hinduism has ever adopted a broad outlook, and therefore, it has not only heartily accepted Lord Buddha, but has also acknowledged him as the10th incarnation of God. Hinduism is not a religion to be tagged with a confined religious practices, faiths and beliefs. Rather, it has accepted the individual preachers and teachers, with a high degree of respect for them. The Sufis and saints have been given love and respect by Hindus, irrespective of the feeling that they hail from a different religious group. In fact, Hinduism is a way of life to be lived with and practised by in any manner that enriches values in society. It does not allow any kind of exploitation by anyone who so ever he or she may be, irrespective of power or position he or she has been holding.

Hinduism believes in incarnation of God on the Earth in one form or another to safeguard the people from miserable and unbearable conditions and to restore religion that opens the door of peace, love, happiness and prosperity. Hindu scriptures and mythological beliefs are testimony to God's birth during the four different ages: Satyuga, Treta, Dwapar and Kaiyuga.It is interesting to observe while reading the Hindu literatures, such as Upnishads, Puranas and other scriptures that God's purpose of incarnating here in human form had not only been to protect the oppressed class from the oppressors but He had also come here to safeguard the Earth, even in the form of animals as well. It is believed that God was born as a Varaha i.e.hog during Satyuga when Hirayakaksha, an Ashur, one of the three kindsDevata(gods),Manushya(man)and Ashur(demon)-- had engulfed this Earth and had taken away to Patal, a deep and dirty region below the Earth, then He reached there and killed him ,and brought it back to its original position. It appears that Hinduism talks about each and every thinganimate and inanimate-- that is in this cosmos.

Hinduism that is tagged with Sanatana Dharma comprises the spiritual laws that govern human beings to come out from this temporal and ethereal world and reach the sacred and righteous place where lie eternal pleasure and salvation as well. It is believed that the eternal laws were made even before the human existence. Our ancient (rishis) seers and sages, with all His blessings, could give form and shape to these laws from Vedic period onward. They have remained committed to discovering the truth that is both physical and metaphysical; that is both real and unreal; that is both covered with darkness and uncovered by light; that is something or nothing and so on. In Isha Upanishad, while invoking, Lord Vishnu, the governor of this universe, it has been observed that

Poornam-adah, poornam-idam, poor-nath poornamudachyate.

Poor-nasya poornam-adaya, poornam-eva-va-sishyate. 1

That is full; this is full. The full comes out of the full.

Taking the full from the full, the full itself remains.

These lines transcend our mind to realize the Divine truth that ever remains divine in all the parts that He has created. Even many other things that our senses cannot sense are also because of the lack of divine sense that we do not have. The Sanatana Dharma looks upon a person as a part of the mighty Whole. The whole is in part and the part is in the whole. Besides being omnipotent the Divine is omnipresent. Such cosmic outlook of Hinduism transcends the humans to feel and realize the unseen with purity of mind and sacredness in belief. On social level, the Hinduism advocates coming out of the sectarian or group dogmas and paves the way for the coexistence of all creatures under the umbrella of Vasudev Kutumbhkam, meaning "The Universe is One Family." In India, Kumbha festival that conglomerates the people from different parts of this nation and abroad is celebrated at four sacred places-Allahabad (Prayag),Haridwar,Nashik and Ujjain. It 
is believed that a few drops of amrita(nectar) had fallen into the rivers at these four places as result of war for possession of amrit kumbh(nectar pot) between Suras and Asuras.

Though it would become a subjective observation when I share my personal experiences and observations about the Kumbha 2013, yet I feel I must bring out what I saw and sensed. I visited Allahabad on 10 March to have holy dip into the most sacred river Ganga.I observed that an enormous number of people from all the sections and religious beliefs were going to take holy bathe and were returning to their homes, with pots filled with Ganga Jal. Their assemblage was in a very orderly manner, with complete surrender of their body and mind. I also observed that many other races from Europe and America were also performing the Hindus' rituals. Some of them had visited here with a view to finding out how such a big festival was celebrated on the bank of the river where billions of people, the number that exceeds many countries' population, assembled there, bathed in the holy river, prayed mother Ganga to shower her blessings on them, their families and the people in the world so that peace, prosperity and progress might come on each door. Some of the devotees were also praying for salvation, for it is believed that a holy dip into Ganga during Kumbh can redeem a person from all the sins he or she has committed.

God does not any create any discrimination among the human beings. It is they who suffer from vices and evils when they possess power, and hence do not allow others to live their lives with free mind and belief. When such situations become intolerably rampant, there appears to be an indispensable need of restoration of dharma so that peace and harmony in universe could be attained. In Gita, Lord Krishna, who it is believed, incarnated during Dwapar age, makes Arjuna aware of His purpose of incarnation and tells him,

yada yada hi dharmasya

glanir bhavati bharata

abhyuthanam adharmasya

tadatmanam srjamy aham 2

Whenever there is decline in religion and people indulge in irreligious activities and do sinful and unlawful deeds, I, for the purpose of uplifting the dharma, shall incarnate time and again during all Ages. Human civilization has witnessed the birth of great people who have executed the work of God through their deeds in one way or another. He further tells Arjuna by inculcating belief and confidence in him,

\section{Paritranaya sadhunam vinasaya ca dushkratam}

Dharma-sansthapanarthya sambhavami yuge yuge3

While telling His objective of incarnation, He also clears Arjuna's doubts and asserts that He will always take birth to punish the wicked and evil doers with a view to safeguarding the good and sacred minded people, thereby restoring dharma and reinstating it to its holy state. The Hindu scriptures illustrate dharma in a very broad sense. In fact, the Santana Dharma affirms that the Ultimate Reality cannot be limited by any name or concept. Here, "I", in Gita, does not stand for an individual Krishna, but it signifies for all individuals who possess the same I and are committed to performing their aims and objectives. "I" also stands for knowing and becoming aware of the Truth that shall help the individuals like Arjuna to realize and go on fighting for the restoration of dharma in an indifferent state of mind that alone shall pave the way for victory. It is worth here to note that success and failure or victory and defeat result into high and low emotive conditions that dominate human mind. With the attainment of the former one becomes highly jubilant and sometimes considers oneself as the sole commander, but in latter's case the same one becomes gloomy and sometimes loses his control on the self. The situation is similar in both the cases. Therefore, He asks Arjuna to be indifferent from such situations and keep on fighting for the cause of dharma without thinking of the result that the war will yield to.

Though war is not the solution of the problems, it sometimes becomes inevitable to punish the wrong and to restore values in society. During Mahabharat i.e. The Great War that took place about five thousand years ago, the war had become unavoidable despite the best possible efforts to prevent it. The loss of humankind was unprecedentedly heavy. Similar kinds of death tolls have taken place in human history mostly as a result of wars and conflicts. Men forget that they can never escape from death. Yet instead of loving and giving respect to human body they exploit the humans and involve their body and mind into undesirable and sinful acts.

\section{Conclusion}

Hinduism has never advocated for war as one of the means for possession of power and glory. It has such deep rooted instincts and feeling for accepting the people of all races and religions that it has been surviving and flourishing day in and day night despite attacks by barbarian minded people and propagation against it by the groups having confined outlook. Such people forget that religion provides the human race with an opening of doors through which they can enter into limitless horizon and explore and experience their self and soul and thereby find some repose. It is never a mechanical activity that one is required to adopt in life. It is, rather, a sacred deed, governed by purity of mind. It is not the finale of human acts, but is the beginning with unending adoption of good and sacred deeds followed by realization of eternal pleasure that links with Him.

Thus, Hinduism is democratic in behaviour. It has never been tempting or forcing people to adopt it in their lives as many religions of the world have done so. It only talks about the principles that help people in living and dealing with mundane affairs. It also crosses the physical boundaries and touches the metaphysical realm wherein the humans realize the purpose of their birth on this earth. 


\section{References}

[2] Chapter 4. Transcendental Knowledge, TEXT 7

[1] An opening invocation prefaced to Isha Upanishad 